\title{
Migration in the Middle Asia and Its Effects on the Labor Market
}

\author{
Füsun ÇELEBİ, Atakan DURMAZ \\ Bayburt University, Bayburt, Turkey
}

\begin{abstract}
Many Middle Asia countries declaring their independence after the splitting of the Soviet Union, cannot meet the economical and social needs of their citizens by falling much behind of the era in terms of industry despite the natural wealth they have. In addition to all these, the problems in the ruling class and the chaos environment have resulted in the migration of many people to alternative living spaces. These migrations have affected labor market both positively and negatively besides the social life. The labor demand increased by the entrance of the immigrants into the market has affected the employee wages and also this situation has affected the life standards of the citizens. In this study, the migration that took place in the countries established after the splitting of the Soviet Union, forming one of the two poles of the world before the cold war, and the effects of this migration on the labor market have been analyzed considering previous studies on the subject. The studies carried out on this subject have yielded various results according to the area in which it is carried out, the time interval it includes, and the period's structure. For this reason, the points of views on the subject are compared by making a long literature review.
\end{abstract}

Keywords: migration, labor market, Middle Asia

\section{Introduction}

Human being has been obliged to emigrate due to various reasons for centuries. While some have emigrated as a result of the brutality of sovereigns, others have done so because of such reasons hunger, famine, and economic factors.

The migrations caused by economic reasons take place generally in a way in which people groups who want to live in better conditions and earn more lead to more developed countries leaving where they live. These migrations affect both positively and negatively not only the countries left but also those arrived. The fact that the unqualified emigrant labor affects the labor market of the country they arrive in as a result of the excess supply they cause could be considered as the most important one among the negative effects. However, the probable deduction effect of the immigrant labor power on costs is one of the most important positive effects which should never be underestimated.

The immigrants affect, in various ways, not only the countries in which they arrive but also in which they

Füsun ÇELEBİ, Associate Professor, Ph.D., Department of Economics, Bayburt University.

Atakan DURMAZ, Research Assistant, Department of Economics, Bayburt University.

Correspondence concerning this article should be addressed to Füsun Çelebi, Bayburt University, Bayburt, Turkey. E-mail: fusuncel@gmail.com. 
were born. The main effect of those is the decrease in unemployment caused by the migration of the unqualified labor power. Apart from this, the exchange income sent by the emigrants to their homelands is considered as a very important foreign resource for many countries.

In this study, the effect of migration on the labor market of the countries having been established in Central Asia especially after the Soviet Union separated is aimed to be analyzed. Firstly, the concept of international migration and the effects of international migration on labor market will be investigated into and then, the effect of migration on Central Asia countries is aimed to be discussed.

\section{International Migrations}

The increase having been experienced in both national and international migration currencies since the second half of the 20th century has caused academic studies to be focused on this area. Different reasons cause individuals to emigrate individually or within groups. In this context, it is possible to explain migration briefly as the moving of people individually or collectively as a result of economic, social, and political reasons (Şahin, 2001). Thinking more comprehensively, migration is the temporary or stable settlement of people in other places after leaving the places where they live for the aim of working or providing themselves with better life conditions (Öngör, 1980).

Migration takes place voluntarily or compulsorily. However, considering the historical events, one can see that the mass migrations have taken place generally because of compulsory reasons. The Migration of Tribes which dates back to 4th century when the Huns trying to escape from the sovereignty of China moved towards the west and settled in the north of Black Sea causing the German tribes who had been living in that region to leave the region and invade the Europe Continent for years laying the foundations of today's Eurpoe states, is the first known mass migration movement (Kinik, 2010). While the mass migrations taking place in different places leads up to the foundation of new cities and states, the intercontinental migrating has had an oversea dimension since the American Continent was discovered (Aksoy, 2012). Since the 16th century, many people living in Europe have migrated collectively to America continent and have settled there. Behind this migration are the economic reasons. The opportunity of agriculture in the large fields within the new continent and the fact that the overseas trade developed much have lead people to settle in this continent collectively. Apart from these, nearly 15 million people have been moved from Africa to America to work as a slave, in the 19th century, millions of people migrated to America and Europe from China and India for working as contract labors, as a result of the two World Wars broke out in 20th century, many people have been obliged to leave their homelands (Giddens, 2010).

Europe countries having been tried to be re-established after the Second World War, which have started to host emigrants from underdeveloped and developing countries to meet the demanded labor power. As this migration movement depending on economic factors has taken place in parallel with the people's wishes, it is possible to be regarded as being based on voluntariness.

General idea about the factors affecting international migration depends on the migration of people from underdeveloped countries to more developed ones for earn more and to live in better conditions (İçduygu, 2009). However, this idea has been changing gradually. A kind of migration from developed countries to underdeveloped ones has been taken place since the developed countries began to spread their economic actions towards various parts of the world. These are (de Tapia, 2003): 
- Permanent settlers;

- Permanent contract labors;

- Permanent professional workers;

- Secret or illegal workers;

- Asylum seekers;

- Refugees.

According to United Nations, those leaving their homelands and moving to other countries need to stay there more than one year to mention about international migration (Gençler, 2004). Economic factors, though being an important factor leading people to move and live in other countries distinct from their homelands, are not the sole factor. There are several factors apart from economic ones. These could be counted as below:

- Migration originating from Economical factors: Migration movements taking place due to people's wish to have better jobs, more income, and, accordingly, a better life;

- Migration originating from Climatic factors: Migration movements caused by climatic conditions and natural events. Events such as drought, famine, and natural disasters are leading factors for people's migration;

- Migration originating from Political factors: Migrations caused by the events such as wars, terror, political pressure which threatens human life. This kind of migration could be caused by problems and instabilities among different parts of a country while it could be among countries;

- Migration originating from educational factors: Migration movements that take place temporarily for educational purposes. While backward migration could take place as the educational process finishes, permanent settlement is also possible even after educational process finishes;

- Brain drain: Migration of well-educated, qualified, expert individuals of an underdeveloped country to developed countries for the aim of having better living conditions, a better status, and better income level;

- Retired migration: Retired migration, including motivations different from the other migration types, refers to the migration of people from generally wealthy North America and North Europe to South America and South Europe costs to spend rest of their life after retirement (Balkiri, Karaman, \& Kurkulak, 2008).

Various theories directed at the reasons of international migration have been developed within migration srudies (Lee, 1996; Wallerstein, 1974). However, the studies carried out accept that the contemporary migration cannot be connected with only one theory and cannot be measured through one viewpoint (Massey et al., 1993). Globalization makes it compulsory to evaluate the migration relationship among countries with different dimensions.

\section{The Effect of International Migration on Labor Market}

According to a study carried out by United Nations: more than 175 million people, 3\% of the world population, live in places different from their homelands (Borjas, 2006). Many developed countries, especially the USA, Canada, and Australia, host these emigrants. The amount of emigrant population hosted by developed countries has reached high levels, $11 \%$ of France's population, 9\% of Germany's population, 11\% of Switzerland's population, and 7\% of United Kingdom's population is comprised of foreign originated people. These crowded emigrant groups have great impacts on both social and economical structure of the countries in which they live. Important conflicts caused by cultural differences and economic factors can be observed 
between the natives and emigrants especially during crisis periods.

The effect that emigrants have on the labor power of the host countries has been an important subject on which many academics have studied. However, contrary to the general opinion, it has been revealed as a result of the studies carried out in the USA and many European countries that migration has no or very little effect affect on the native workers employment or their salaries (Dustmann, Fabbri, \& Preston, 2005). However, considering the studies analyzing the effects of migration in detail, the effect of migration on labor market varies according to the qualified worker portion in total emigrant group and the labor market's structure.

The fact that migration towards OECD countries is more than the rest of the world and also there has been a gradual increase during the recent years is stated in the study carried out by Docquier, Özden, and Peri (2001). It was revealed in 2009 that $10 \%$ of the OECD countries' population is foreign originated people. However, contrary to what is believed in this study, it has been revealed that the many migration movements among OECD countries have been from one OECD country to another and the portion of high-school graduate in the emigrant group is higher than those in the migrated country. Accordingly, it can be said that the migration towards the OECD country is mainly brain drain. It has been revealed that as those migrating to OECD countries are generally qualified workers, although migration movement towards this region affects employment and salaries of the unqualified workers in that country negatively, it has no negative effect on the qualified works.

\section{The Structure of Migration in Central Asia and the Effect of Labor Migration on Employment Market}

Central Asia countries' population has been in a new structuring process since the Soviet Union separated and new 15 states established. While, initially, migration intention was high because of political and ethnical conflicts, economic reasons came forward later. Especially after the Soviet Union, as the structure of migration is analyzed within five different periods, the reasons why the region's people headed towards come up. In the first step (1991-1992), population movements were the same as in the last years of 1980s, and were shaped according to discriminations and ethnical based conflicts. In the second step of migration period (1993-1995), political and ethnical factors continued their dominance, while about $57 \%$ of originally Kazakh migrants live in emergent countries, the rest live in Mongolia (Korobkov, 2007). In the third step (1996-1999), as political factors lost their significance, social and economic factors accelerated the region's people's movements. In this period, while the number of emigrants arriving in Russia, Ukraine, Belarus, and Moldova decreased, there was an increase in both permanent and temporary labor migration in Azerbaijan and Central Asia. Also, the growing bureaucratic structuring, the effects of international laws and the negative attitudes towards emigrants slow down the migration tendency. In the fourth step (2000-2005), there were attempts to construct legal infrastructure of emigrant policy, while in the fifth step, after 2005, there was a process in which temporary emigrants were made permanent, and employees were punished in case of employing illegal emigrants (Korobkov, 2007).

In Figure 1, the increase portion of migration towards Russia between 1992 and 2010 is shown. After the country separated, while the highest amount of migration was in 1994, the number of people migrating decreased in the following years and reached its lowest number in 2003. The number of migration in 2003 increased less than those in 1990s, and as of the year of 2010, being in a decrease proccess, reached a number of below 200 thousand. 


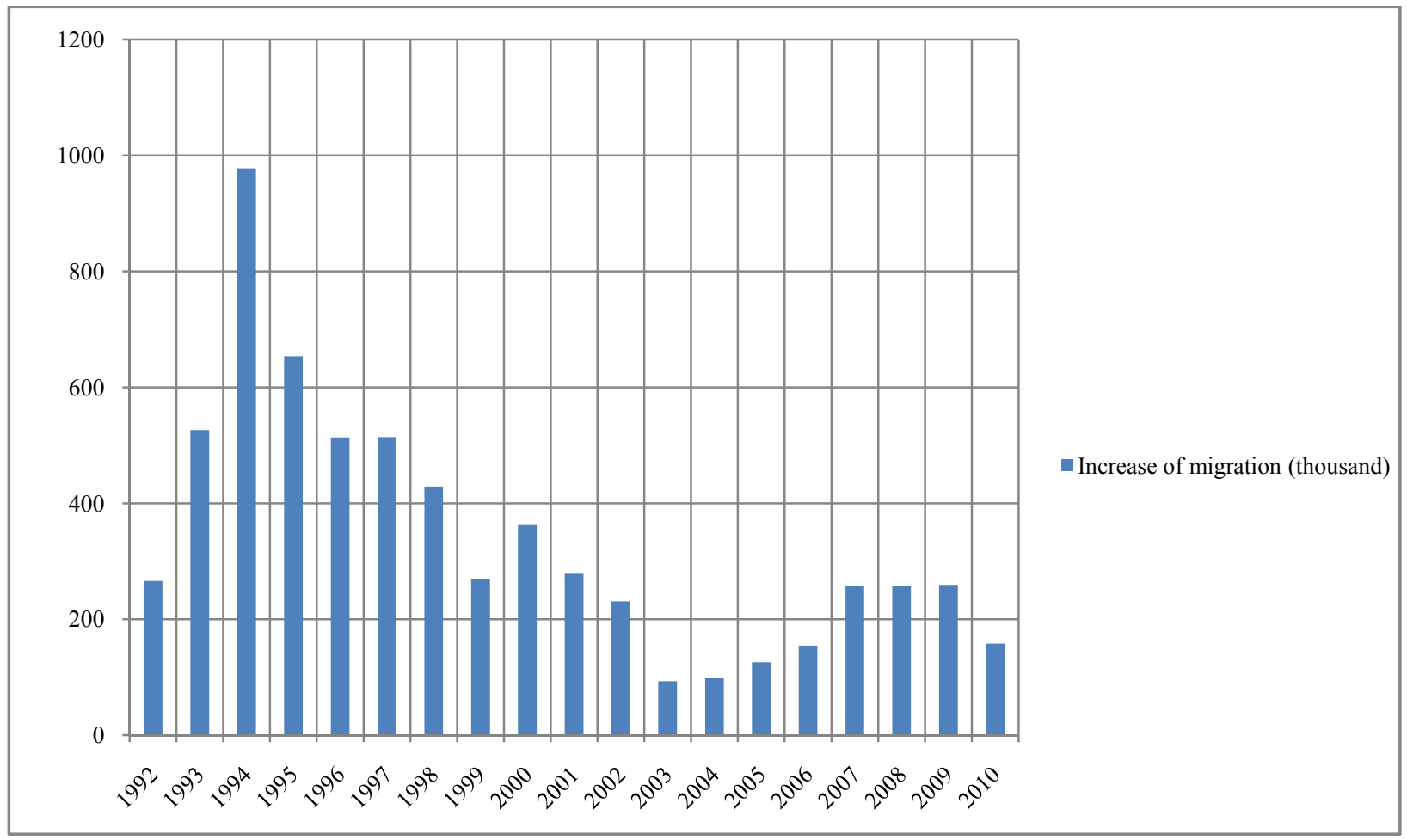

Figure 1. The increase in the migration amount of Russia between 1992 and 2010 (Thousand).

Table 1

Country Based Distribution of Those Migrated Between 1997 and 2010

\begin{tabular}{lrrrrrrrr}
\hline & 1997 & \multicolumn{1}{c}{2000} & \multicolumn{1}{c}{2005} & \multicolumn{1}{c}{2006} & \multicolumn{1}{c}{2007} & \multicolumn{1}{c}{2008} & \multicolumn{1}{c}{2009} & 2010 \\
\hline Azerbaijan & 29,878 & 14,906 & 4,600 & 8,900 & 20,968 & 23,331 & 22,874 & 14,500 \\
Armenia & 19,123 & 15,951 & 7,581 & 12,949 & 30,751 & 35,216 & 35,753 & 19,890 \\
Belarus & 17,575 & 10,274 & 6,797 & 5,619 & 6,030 & 5,865 & 5,517 & 4,894 \\
Kazakhstan & 235,903 & 124,903 & 51,945 & 38,606 & 40,258 & 39,964 & 38,830 & 27,862 \\
Kirghizistan & 13,752 & 15,536 & 15,592 & 15,669 & 24,731 & 24,014 & 23,265 & 20,901 \\
Moldova & 13,750 & 11,652 & 6,569 & 8,649 & 14,090 & 15,519 & 16,433 & 11,814 \\
Tadzhikistan & 23,053 & 11,043 & 4,717 & 6,523 & 17,309 & 20,717 & 27,028 & 18,188 \\
Turkmenistan & 16,501 & 6,738 & 4,104 & 4,089 & 4,846 & 3,962 & 3,336 & 2,283 \\
Uzbekistan & 39,620 & 40,810 & 30,436 & 37,126 & 52,802 & 43,518 & 42,539 & 24,100 \\
Ukraine & 138,231 & 74,748 & 30,760 & 32,721 & 51,492 & 49,064 & 45,920 & 27,508 \\
Total & 547,386 & 326,561 & 163,101 & 170,851 & 263,277 & 261,170 & 261,495 & 171,940 \\
\hline
\end{tabular}

Considering the migration data about countries between 1992 and 2010, it is observed that there are 547,386 emigrants in 1997, and also while Kazakhstan comprises $43 \%$ and Ukraine comprises $25 \%$ of this amount, the rest is comprised of Uzbekistan, Azerbaijan, and Tadzhikistan. It is possible to conclude the fact that as Kazakh language became dominant in Kazakhstan, Kazakhs had a voice in policy and economy, and there was a weak economy in that region, there has been an increase in the number of emigrants (Dornis, 1997). Migration from Kazakhstan to Russia decreased after 1997, and the number was 27,862 in 2010. The reason for this decrease was 
the improvement in Kazakhstan's economy despite the recession in Russia's economy (Salt, 2005). In the same way, the number of emigrants from Ukraine to his close neighbor has decreased until 2007, and although it increased again in 2007, it started to decrease again after 2007. The emigrants leaving Ukraine prefer not only Russia, but also East Europe, Germany, and Israel with the intention of settling, depending on the economy in Russia (Rybakovsky \& Ryazantsev, 2005). Such factors as militarial ethnical conflicts, downwardness of Russia population and Russian language in Kirghizistan have affected the migration process, and although it increased in the years between 1997 and 2007, Russia was at the fourth place among the emigrant countries in 2010. As people migrating from Kirghizistan are high qualified people, their migration causes a decrease in the country's economically active population and qualified workers working in the industrial, transportation, construction sectors (Ergeshayev, 2006). While, general the number of people migrating from Uzbekistan to Russia is fluctuating, it was 24,100 in 2010. As a result of the economic growth in Kazakhstan and Russia, the number of people migrating from Tajikistan and Uzbekistan increased in 2007, and then it decreased due to the economic crisis (Abdullaev, 2008).

\section{The Structure of Labor Migration in Central Asia and Its Affect on Labor Market}

The fact that life standards decreased and unemployment increased with the shift into market mechanism in Central Asia led people to search for alternative income resources in various countries. Accordingly, this fact accelerated labor migration (Korobkov \& Zaionnchkovskaia, 2004). After Soviet Union separated, people from Azerbaijan, Georgia, Kirghizistan, Armenia, Moldova, Uzbekistan, Tajikistan, and Ukraine started working in Russia without getting visa. A large amount of the workers is comprised of males, and also most of them works at construction, services, trade, and agriculture sectors (Retrieved from http://www.ios-regensburg.de/fileadmin/doc/ios_db/Remittances_CIS12_2004-2008.pdf).

As it can be seen from Table 2, the share of remittance income in Gross Domestic Product (GDP) is Tajikistan with an amount of $31 \%$ followed by Moldova and Kirghizistan respectively. It is possible to conclude the fact that migration tendency has increased in Tajikistan as educational processes are left half finished because of the civil war, large amount of the population work at agricultural sectors whose average salary is low, and their qualifications are inadequate (Marat, 2009). Migration tendency in Moldova varies in three ways. In the first step, it was generally for economical and commercial purposes because of the high poverty level depending on the effects of economic crisis in Russia in the second step after 1997. In the same way, the period after 2007 refers to a period in which the share of Moldavian exists in foreign labor market, and the remittance income increases $\begin{array}{lllll}\text { except for } & 2009 & \text { (Retrieved }\end{array}$ http://siteresources.worldbank.org/INTECA/Resources/WBMoldovaReport.pdf). The fact that remittance income in Kirghizistan increases except for 2009, the crises in Kazakhstan and Russia led both countries impose a quota on those to be employed refer to a decrease in remittance in 2009 (Retrieved from http://www.warwick.ac.uk/fac/soc/pais/researc/nsc/projects/templer/publications/cg_central_asia_migrants_and _the_economic_crisis_in_pdf.pdf). While, the portion of outflow of foreign currency by workers in Gross Domestic Product is most in Tajikistan with an amount of $15.2 \%$, Kirghizistan's share is $6.2 \%$. It is determinable that the outflow of foreign currency is shaped according to those transferring from Kirghizistan to Tajikistan and Uzbekistan, and from there to Russia and Kazakhstan (Collins, 2006). 
Table 2

Workers Remittance Inflow and Outflow in Central Asia Countries Between 1997 and 2011

\begin{tabular}{|c|c|c|c|c|c|c|c|c|c|c|c|c|c|c|c|}
\hline $\begin{array}{l}\text { Transfer Inflow } \\
\text { Million USD }\end{array}$ & 1997 & 1999 & 2000 & 2001 & 2002 & 2003 & 2004 & 2005 & 2006 & 2007 & 2008 & 2009 & 2010 & $2011 \mathrm{e}$ & $\begin{array}{l}\% \text { of } \\
\text { GPD } \\
2010 \\
\end{array}$ \\
\hline Azerbaijan & .. & 54 & 57 & 104 & 182 & 171 & 228 & 693 & 813 & 1.287 & 1.554 & 1.274 & 1.432 & 1.885 & 2.5 \\
\hline Armenia & 136 & 95 & 87 & 94 & 131 & 168 & 435 & 498 & 658 & 846 & 1.062 & 769 & 996 & 1.254 & 8.8 \\
\hline Belarus & 295 & 209 & 139 & 149 & 140 & 222 & 257 & 255 & 340 & 354 & 680 & 589 & 589 & 722 & 1 \\
\hline Kazakhstan & 60 & 64 & 122 & 171 & 205 & 148 & 166 & 178 & 186 & 223 & 192 & 261 & 291 & 270 & 0.2 \\
\hline Kirghizistan & 3 & 18 & 9 & 11 & 37 & 78 & 189 & 322 & 481 & 715 & 1.232 & 992 & 1.275 & 1.500 & 20.8 \\
\hline Moldova & 20 & 112 & 179 & 243 & 324 & 487 & 705 & 920 & 1.182 & 1.498 & 1.897 & 1.211 & 1.392 & 1.562 & 23.2 \\
\hline Tadzhikistan & .. & .. & .. & .. & 79 & 146 & 252 & 467 & 1.019 & 1.691 & 2.544 & 1.748 & 2.254 & 2.680 & 31 \\
\hline Turkmenistan & .. & .. & .. & .. & .. & .. &.. &.. & .. &.. & .. &.. &.. &.. & .. \\
\hline Uzbekistan & .. &.. & .. & .. &.. & .. &.. &.. & .. & .. & .. &.. & .. &.. &.. \\
\hline Ukraine & 12 & 18 & 33 & 141 & 209 & 330 & 411 & 595 & 829 & 4.503 & 5.769 & 5.073 & 5.607 & 6.619 & 3,9 \\
\hline \multicolumn{16}{|l|}{$\begin{array}{l}\text { Transfer out } \\
\text { flow million } \\
\text { USD }\end{array}$} \\
\hline Azerbaijan & 19 & 77 & 101 & 142 & 235 & 169 & 200 & 269 & 301 & 435 & 593 & 652 & 961 &.. & 1.9 \\
\hline Armenia & 5 & 12 & 5 & 21 & 24 & 27 & 138 & 152 & 154 & 176 & 185 & 145 & 157 &.. & 1.8 \\
\hline Belarus & 141 & 97 & 58 & 77 & 68 & 65 & 82 & 95 & 93 & 109 & 141 & 112 & 104 &.. & 0.2 \\
\hline Kazakhstan & 522 & 356 & 440 & 487 & 594 & 802 & 1.354 & 2.000 & 3.033 & 4.303 & 3.559 & 3.058 & 3.020 &.. & 2 \\
\hline Kirghizistan & 29 & 51 & 45 & 55 & 57 & 55 & 83 & 125 & 150 & 220 & 196 & 188 & 297 & .. & 6.2 \\
\hline Moldova & 20 & 25 & 46 & 59 & 57 & 67 & 67 & 68 & 86 & 87 & 115 & 104 & 117 &.. & 2.2 \\
\hline Tadzhikistan &.. &.. & .. & .. & 13 & 64 & 119 & 145 & 395 & 184 & 199 & 124 & 856 &.. & 15.2 \\
\hline Turkmenistan & 4 &.. & .. &.. &.$\cdot$ &.. &.. & .. &.. &.. &.. & .. &.. &.. &.. \\
\hline Uzbekistan & .. & .. & .. & .. &.. & .. &.. & .. & .. & .. &.. & .. &.. & .. &.. \\
\hline Ukraine & 4 & 3 & 10 & 5 & 15 & 29 & 20 & 34 & 30 & 42 & 54 & 25 & 24 &.. & 0 \\
\hline
\end{tabular}

Note. ".." means data not available; e: estimate.

Table 3

Average Salaries and Wages Between 1994 and 2008 (Dollars)

\begin{tabular}{lrrrrrrrrrr}
\hline & 1994 & 1998 & 2000 & 2001 & 2002 & 2003 & 2004 & 2005 & 2006 & 2008 \\
\hline Russia & 110 & 108 & 79 & 111 & 139 & 179 & 234 & 305 & 391 & 718 \\
Azerbaijan & 13 & 44 & 49.5 & 55.8 & 64.9 & 78.8 & 101.2 & 130.8 & 166.8 & 317 \\
Armenia & 6 & 36 & 42.1 & 44.1 & 47.7 & 60.1 & 81.4 & 113.7 & 149.8 & 293 \\
Belarus & 27 & 106 & 73.6 & 86.6 & 104 & 120 & 160 & 215 & 271 & 396 \\
Kazakhstan & 48 & 119 & 101 & 117.9 & 132 & 154 & 208 & 256 & 323 & 485 \\
Kirkhizistan & 22 & 40 & 25.7 & 39 & 35 & 43 & 52 & 63 & 81 & 137 \\
Moldova & 26 & 47 & 32 & 42 & 51 & 63 & 89 & 104 & 129 & 245 \\
Tadzhikistan & 16 & 12 & 8.5 & 9 & 11 & 14 & 20 & 26 & 35 & 63 \\
Turkmenistan &.. &.. &.. &.. &.. &.. &.. &.. &.. &.. \\
Uzbekistan & 27 & 47 &.. & 39 & 39 & 41 & 52 &.. &.. &..
\end{tabular}

Note. ".." means data not available. 
According to Table 3, average salary in Russia increases generally except for that in 1998, crisis period, and reached 718 dollars in 2008. In the same way, average salary in Kazakhstan too, is higher than many other countries, and increases except for 2000. Apart from Kazakhstan, the countries with high salaries are Ukraine, Belarus, and Azerbaijan followed by Armenia and Moldova. The countries with lowest salaries are Kirghizistan and Tajikistan. The fact that remittance income is highly results in the migration of people to countries with higher salaries to have better life standards. In January, 2012, while the average salaries are supposed to be 795 and 630 dollars in Russia and Kazakhstan respectively, it is supposed to be about 110 dollars Tajikistan (Retrieved from http://news.am/eng/news/101025.html). It is known that Russia's economy will grow and remittance income will increase by means of the increase in oil prices and economic recovery. Also, according to the forecasts, remittance out flow from Europe and Central Asia will rise from 6.5\% to 10.4\% from 2011 to 2012.

\section{Conclusions}

After the separation of Russia, the second biggest migration-receiving country, while ethnic origin based migration tendency of those Russian originated and Russian speaking increased, the structure of migration changed depending on the economic disruption. The civil wars in Tajikistan, Kirghizistan, and Azerbaijan-Armenia regions prevented people from finishing their education and getting qualified training. In this period, at the same time, with the shift into market economy, the fact that new arrangements were made and they could not find positions suitable for their qualifications led people to search for new ways of income. Accordingly, the process of migrating to close neighbours started and then continued towards Europe Countries, Israel, and America. It can be said that the citizens of the region migrate to other places with higher average salaries to get better life standards and live in better conditions, and especially those in Kirghizistan, Tajikistan, and Uzbekistan headed for Kazakhstan and Russia. Also, the fact that the exchange income comprises a large amount of gross Domestic Product of Tajikistan, Kirghizistan, and Moldova underlines again the importance of emigrant income. As Russia made it easier to get visa for the places where it was dominant, labor migration increased significantly and it became an important country in terms of outflow of foreign currency. Labor migration, playing an important role on such sectors as construction, services and trade, is expected to increase even if it would not be at the same lever with that in 1990s. It could be said that Russia's and Kazakhstan's continuing economic growth depending on the increases in oil prices will be important for Tajikistan, Kirghizistan and Uzbekistan from where they allow immigrants, and also the number of people migrating will increase. Accordingly, as a result of the economic crises, countries will set measures to present employment market which will let to a decrease in workers' incomes.

It can be said that, in the new period, while Russia will keep its importance, a new kind of structuring will come out in which qualified labor power will, instead of working in poor countries, shift towards developed countries lacking labor. Apart from this, the moderate changes in the economic structure make economic and social factors be more dominant in the migration period based on ethnic and political reasons after Soviet Union separated.

\section{References}

Abazov, R. (2009). Current trends in migration in the common wealth of independent states, human development research paper. Retrieved from http://hdr.undp.org/en/re ports/global/ hdr 2009/ papers/HDRP_2009_36.pdf 
Abdullaev, E. V. (2008). Labour migration as phenomenon of developing societies, labour migration in Uzbektstan: Social, legal and gender aspects. Tashkent.

Aksoy, Z. (2012). Uluslar arası göç ve Kültürlerarası İletişim. Uluslararası Sosyal Araştırmalar Dergisi, 5(20), 292-303.

Balkiri, C., Karaman, Z. T., \& Kırkulak, B. (2008). Yabancı Emekli Göçünün Sosyal ve Ekonomik Etkileri: Antalya ve Çevresi Üzerine Ampirik Bir Çalışma. Uluslararası Emekli Göçünün Sosyal ve Ekonomik Etkileri: Antalya Örneği (pp. 8-38). Antalya: Der. Canan Balkırı.

Beloborodov, I. (2011). Demographic situation in Russia in 1992-2010. Retrieved July 01, 2012, from http://www.demographia.ru/eng/articles/index.html?idR=71\&idArt=1928

Borjas, G. (2006). The impact of migration on the labor market. http://www.jvi.org/fileadmin/jvi_files/Warsaw_Conference/Papers_and_Presentations/Borjas_paper.pdf

Collins, K. (2006). The logic of clan politics in central Asia. Cambridge: Cambridge University Press.

Daniyar, K. (2008). Kyrgyzstan's average wage rates second to last. Retrieved August 01, 2012, from http://eng.24.kg/cis/2008/07/31/5732.html

de Tapia, S. (2003). New patters of irregular migration to Europe. Retrieved from $\mathrm{http} / /$ www.coe.int/t/dg3/migration/documentation/Migration\%20management/53000_New_patterns_of_irregular_migration _in_Europe_en.pdf

Docquier, F., Özden, Ç., \& Peri, G. (2011). The labor market effect of migration and emigration in OECD countries. IZA Discussion Paper No. 6258.

Dornis, C. (1997). Migration in the Russian Federation since the mid-1980s: Refugees, immigrants and emigrants (pp. 77-117). USA: Rainer Münz ve Myron Weiner.

Dustmann, C., Fabbri, F., \& Preston, I. (2005). The impact of migration on the british labour market. The Economic Journal, 115, F324-F341.

Ergeshayev, U. (2006). Trends and migration processes in Kyrgyzstan, migration perspectives Eastern Europe and central Asia. $\begin{array}{lllll}\text { Austria: } & \text { Roger } & \text { Rodriguez } & \text { Rues. } & \text { Retrieved }\end{array}$ $\mathrm{http} / / / \mathrm{src}$. auca.kg/pdf/Migration_Perspectives_Eastern_Europe_and_Central_Asia.pdf\#pge=51

Federal State Statics Service. (2011). Population, international migration. Retrieved July 02, 2012, from http://www.gks.ru/bgd/regl/b11_12/IssWWW.exe/stg/d01/05-08.htm

Gençler, A. (2004). Avrupa Birliği'nin Göç Politikası. Sosyal Siyaset Konferansları Dergisi, 49, 173-197. Retrieved from http://iudergi.com/index.php/sosyalsiyaset/article/viewFile/461/416

Giddens, A. (2010). Göçmenlerin Emek Piyasası Üzerindeki Etkisi, Sosyoloji Başlangıç Okumaları (pp. 522-527). Ed. Anthony Giddens, Ankara: Say Yayınları.

İçduygu, A. (2009). International migration and human development in Turkey. UNDP Human Developments Research Paper 2009/52. Retrieved from http://hdr.undp.org/en/reports/global/hdr2009/papers/HDRP_2009_52.pdf

International Crisis Group. (2010). Central Asia: Migrants and the economic crisis, Asia Report, 2010. Retrieved from http://www.warwick.ac.uk/fac/soc/pais/research/nsc/projects/templer/publications/cg_central_asia_migrants_and_the_econo mic_crisis_in_pdf.pdf

Kinik, K. (2010). Göç, Sürgün ve Iltica. Retrieved from http://www.amnesty.org.tr/ai/node/1538

Korobkov, A. V. (2007). Migration trends in central Eurasia: Politics versus economics. Communist and Post-Communist Studies 40(2), 169-189.

Korobkov, A. V., \& Zaionchkovskaia, Z. A. (2004). The changes in the migration patterns in the post-Soviet states: The first decade. Communist and Post-Communist Studies, 37(4), 481-508.

Lee, E. S. (1966). A theory of migration. Demography, 3, 47-57.

Marat, E. (2009). Labour migration in central Asia implications of the global economic crisis. Washington: Central Asia: Caucasus Institute Silk Road Studies $\quad$ Program. http://www.silkroadstudies.org/new/docs/silkroadpapers/0905migration.pdf

Massey, D. S., Arango, J., Hugo, G., Kouaouci, A., Pellegrino, A., \& Taylor, E. J. (1993). Theories of international migration: Review and appraisal. Population and Development Review, 19(3), 54-77.

Mohapatra, S., Ratha, D. \& Silwal, A. (2010). Outlook for remittance flows 2011-2012. Retrieved from http://INTPROSPECTS/Resources/3349341110315015165/MigrationAndDevelopmentBrief13.pdf

Öngör, S. (1980). Coğrafya terimleri sözlüğ̈̈. Ankara: Türk Dil Kurumu Yayınları. Retrieved from http://tdkterim.gov.tr 
Rybakovsky, L., \& Ryazantsev, S. (2005). United Nations expert group meeting on international migration and development. Retrieved from http://www.un.org/esa/population/meetings/ittmigdev2005/P11_Rybak ovsky\&Ryazantsev.pdf

Şahin, C. (2001). Yurt Dışı Göçün Bireyin Psikolojik Sağlığı Üzerindeki Etkisi İlişkin Kuramsal Bir İnceleme. G. Ü.Gazi Eğitim Fakültesi Dergisi, 21(2), 57-67.

Salt, J. (2005). Current trends in international migration in Europe. Strasbourg: Council of Europe Publishing.

The CIS Inter-state Statistics Committee. (2012). Average wage in Armenia and CIS countries data. Retrieved June 30, 2012, from http://news.am/eng/news/101025.html

Wallerstein, I. (1974). The modern world system: Capitalist agriculture and the origins of the European world economy in the sixteenth century. New York: Academic Press.

World Bank. (2010). Strengthening the link between migration and development. Retrieved from http://siteresources.worldbank.org/INTECA/Resources/WBMoldovaReport.pdf

World Bank. (2012). Annual remmitances data. Retrieved June 30, 2012, from http://econ.worldbank.org/WBSITE/EXTERNAL/EXTDEC/EXTDECPROSPECTS/0 